\title{
ANALYSIS OF THE RELATION BETWEEN INFLATION AND FOREIGN EXCHANGE RATES FOR THE NORTHERN REGION OF IRAQ
}

\author{
Arzdar KIRACI ${ }^{1}$, Semih Serkant AKTUĞ ${ }^{2}$, Farhang Abdulkareem AQRAWI ${ }^{3}$, Mehmet DAĞ ${ }^{4}$
}

\begin{abstract}
The purpose of this study is to examine the relation between the inflation rate, foreign exchange rates of the major currencies used in the northern region of Iraq (NRI), money supply and gross domestic product (GDP) for the period 2008-2016. It is notable that the region suffers from high inflation rates and there were fluctuations in foreign exchange rates after the fall of the former Iraqi regime in 2003. This is the first article about this subject for NRI using an error correction model and the results indicate that there is a long-run relation between variables. The relation between US Dollar and inflation in the region is positive and statistically significant. There is a negative relation between Euro and inflation, which is also statistically significant. NRI imports many goods and services from Turkey, but a surprising result is that the Turkish Lira variable is not statistically significant. This may be due to the fact that import payments are done with Dollars and not Turkish Liras. There is also a negative long-run relation for the variables GDP and money supply, which are not statistically significant. In the analysis, money supply by the Iraqi Central Bank was used as the money supply variable, but the amount of money supply in the NRI is not proportional to the amount offered by the Central Bank, there is no advanced banking system in the region. The amount of Dinar coming into the region consists of converting the oil export revenues into Iraqi dinar and supplying these Dinars as payments to the market. Therefore, the NRI money supply will depend on the oil revenues and the Dollar, which makes money supply variable statistically insignificant.
\end{abstract}

Keywords: Inflation Rate, Foreign Exchange Rate, Money Supply, Gross Domestic Product, Error Correction Model.

JEL Classification: E31, F31, 047

\section{KUZEY IRAK BÖLGESINDE ENFLASYON VE DÖVIZ KURLARI ARASINDAKi ILIŞKi- NIN DÖNEMSEL BIR ANALIZI: 2008-2016}

Öz

Bu çalışmanın amacı; enflasyon, Irak'ın kuzey bölgesinde (IKB) kullanılan ana para birimlerinin döviz kurları, para arzı ve gayri safi yurtiçi hasıla (GSYH) değişkenleri arasındaki ilişkiyi 2008-2016 dönemi için incelemektir. Bölgenin yüksek enflasyon oranından muzdarip olması ve 2003 yılında eski Irak rejiminin düşmesinden sonra döviz kurlarında dalgalanmalar olması dikkat çekicidir. Bu çalışma, IKB için bir hata düzeltme modeli kullanan konudaki ilk makaledir. Sonuçlar değişkenler arasında uzun vadeli bir ilişki olduğunu göstermektedir. ABD Doları ile bölgedeki enflasyon arasındaki uzun vadeli ilişki pozitif ve istatistiksel olarak anlamlıdır. Euro ile enflasyon arasında negatif bir ilişki vardır ve bu istatistiksel olarak anlamlıdır. IKB Türkiye'den birçok mal ve hizmet ithal ediyor olmasına rağmen şaşırtıı bir sonuç, Türk lirası değişkeninin istatistiksel olarak anlamlı olmaması. Bunun sebebi, ithalat ödemelerinin Türk Lirası ile değil Dolar ile yapılması nedeniyle olabilir.

GSYH ve para arzı değişkenleri için istatistiksel olarak anlamlı olmayan negatif bir uzun vadeli ilişki tespit edilmiştir. Para arzı ve enflasyon oranı arasındaki ilişki istatistiksel olarak anlamlı değildir, çünkü 2014'ten bugüne para arzındaki değişim IKB'den ihraç edilen petrol gelirine dayanmaktadır, yani Irak ekonomisinin para arzına bağlı olmama olasılığıdır.

Anahtar Kelimeler: Enflasyon Oranı, Döviz Kuru, Para Arzı, Gayri Safi Yurtiçi Hasıla, Hata Düzeltme Modeli. JEL SInıflandırması: E31, F31,047

${ }^{1}$ Prof. Dr., Siirt University, Faculty of Economics and Administrative Sciences, Department of Economics, arzdar.kiraci@gmail.com, ORCID:0000-0001-6123-2508

2 Assist. Prof. Dr., Siirt University, Faculty of Economics and Administrative Sciences, Department of Economics, semih.aktug@gmail.com, ORCID:0000-0002-9745-0010

${ }^{3}$ Farhang Abdulkareem AQRAWI, Iraq Ministry of Education, farhangabdulkareem.1988@gmail.com

${ }^{4}$ Assist. Prof. Dr., Siirt University, Faculty of Economics and Administrative Sciences, Department of Public Finance, ORCID:0000-0003-2206-2184

The results of this paper are derived from Aqrawi (2018). 


\section{Introduction}

The purpose of this study is to analyze the relation between inflation and foreign exchange rates, money supply and gross domestic product (GDP) in the Northern Region of Iraq (NRI) during the period 2008-2016. The motivation of this study comes from the fact that since 2003 the economy of the NRI suffers from high inflation rates and fluctuations in foreign exchange rates (Badawah, 2015; Omar, 2017). However, it is essential to pay attention to these phenomena and factors that exacerbate these variables in light of the financial crisis experienced by the region, to help the provincial government to take necessary actions to solve these problems.

Inflation is a recurring phenomenon in all developed and developing economies equally. Nevertheless, in developing economies, it is becoming more severe compared to developed economies (Badawah, 2015). The quantity theory of money states that there is a direct relation between money supply and inflation. However, as shown in the following parts, there is a large deviation between these two variables, the data for the NRI implies that there are other factors for high rates of inflation in this region. Most of the consumer products are imported into the region; an increase in exchange rates will increase inflation or an economic boom will subsequently increase inflation. Consequently, the model in this paper includes foreign exchange rates and GDP in the model.

In this context, this study is structured into three sections. The following section is dedicated to the theoretical framework of inflation, foreign exchange rates, money supply, and GDP for NRI. Their origins, reasons, types, effects are investigated and summarized. The third section is devoted to measuring the relation between these variables using an error correction method. Stationarity and cointegration are checked in this section, and the results are presented. The last section presents the conclusions and proposals.

\section{Literature Review}

The relation between the inflation rate and foreign exchange rates has raised the interest of many economists at the global and international level, so, the current study will review some studies that are related to the topics. This study is different from earlier studies, especially on the studies carried out for the NRI. This study uses the method of cointegration to achieve its objectives in measuring the relation between the inflation rate and foreign exchange rates. There is no scientific research about the NRI investigating the variables in this article on this subject.

There is one similar article for NRI; namely, the article by Badawah (2015). It investigates only the relation between Iraqi Dinar against the US Dollar (USD) by using the error correction model (ECM) for the province of Erbil and the period 2008-2014. In this model money supply, which is one of the main causes of inflation is not included in the model. Therefore, the model in this article contains more variables and might produce unbiased and more accurate results.

Badawah (2015) also provides some explanations for exchange rate fluctuations and inflation in the NRI. The study finds that the Johansen test gives an equation for long-term cointegration between the USD/Dinar exchange rate and inflation during the study period. There is a long-run relation between the high inflation rates and the depreciation of the Dinar against the USD. The results also show that the rise of inflation by $1 \%$ leads to a decrease in the value of the Dinar against the USD by $0.16 \%$. Further, the study shows that there is a long-run balance between the exchange rate and inflation, and this relation is moving from inflation to the exchange rate. However, the rise of inflation by $1 \%$ should have led to a decrease in the value of the Dinar against the USD by $1 \%$. This implies that other variables should have been included in the model. Furthermore, inflation is an endogenous variable, which can be controlled by the NRI, but the foreign exchange rate cannot be controlled in a free-market economy. Therefore, the exchange rate can be considered as an exogenous variable, which is used in this way in this article.

Omar (2017) investigates the consumer price indexes in Erbil governorate for the period 20092015 and the reasons for the direction of changes in consumer price indices as well as inflation 
rates. The most important are the average of the annual inflation rate and the exchange rate that reached $63.6 \%$ and $5.874 \%$. The increase in incomes has played a prominent role in rising prices; also, the implementation of the policy of consumer support by the government, especially in water, electricity, and transport affected prices.

Smaail (2008) tests the impact of the exchange rate in trade (internal and external) for the city of Erbil for the period 1994-2006. This study aims to analyze the impact of the changes that occurred in the exchange rate and its impact on the commercial movements in the province of Erbil. The study finds that the fluctuation occurred in the exchange rate old edition known as Swiss edition and the new edition so-called Bremer edition for the period 1994-2006, and they directly affected the general level of prices of food and other consumer goods. Moreover, these fluctuations reflected itself in the movement of business, and the reasons for this are the circumstances experienced by the city of Erbil. Furthermore, the study revealed that changes in the exchange rate in the markets of Erbil during the period 2003-2006 affected the fluctuation in the level of prices of building materials, cars, electrical materials, and woodworking materials. These imported goods after the lifting of the second economic sanctions affected inflation as well as the exchange rate. Therefore, the exchange rate is included in the model part of this paper.

There are also articles about this subject for Iraq. Eas (2013) analyzes the inflation rates in Iraq for the period 2000-2010. It aims to explain the relation between the inflation rate and the exchange rates of the Dinar against the USD by estimating the model of the function using the appropriate statistical methods and by using the SPSS program in interpreting the results. The study indicates that there is a relation between the two variables; the Dinar has less than its proper value in the market during the 1990s. Moreover, the USD began to play its role afterwards in the Iraqi economy where most of the transactions and commercial transactions held through it. The highest rate of inflation in Iraq in 2006 was $53.1 \%$ that was caused by high prices of oil derivatives (this was clear through the data of the bulletin of the central bureau of statistics for the data records). Furthermore, Iraq's inflation rate fell in 2010 to 2.5 percent due to the decline in the price of petroleum products and improvements in national currency. In addition, the absence of custom fees, the lower rate of annual prices in food and th rented housing prices these factors decreased the inflation rate.

Abbas (2008) investigates the impact of inflation on the exchange rate for the period 19902005. This study aims to identify the performance of economic policies implemented during that time period. It tries to develop solutions that prevent a repeated crisis by adopting balanced monetary and fiscal policies that work in an integrated manner to improve economic performance, thus resulting positively on the stability of the exchange rate. The study reaches some conclusions, the most essential being the existence of a substantial impact of inflation on the exchange rate of the Dinar against the USD during the analysis period. Furthermore, government expenditure not justified by the previous regime and misguided economic policies resulted in increasing the inflation rate. Lower rates of GDP impacted negatively on the Dinar exchange rate. However, the study found that the actions of the monetary authorities represented by the establishment of a public auction for the sale of foreign currency was good in the stabilization of the exchange rate of the USD exchange rate.

Khanjar (2010) highlights and focuses on the paths of inflation in the Iraqi economy for the period 1990-2007 and possible future trends. It aims to detect the pathways of inflation in the Iraqi economy by tracking the causes and consequences of structural imbalances within the economy and it evaluates the effectiveness of economic policies affecting inflation or their contribution to inflationary pressures. Moreover, it predicts a vision for future economic policies that ensure the continuation of the process of development and reconstruction while at the same time reducing inflationary pressures. Subsequently, the study finds some conclusions where the most notables are the rise in food prices are responsible for more than $50 \%$ of the volume of inflation in consumer prices, in addition to the impact of the rise in prices of other goods cumulatively, which 
led to the collapse of real incomes of low-income class. Further, the study revealed that during the period 2003-2007, high inflation rates in the fuel and lighting sector had a significant impact on the inflation wave that affected most economic sectors such as transport and housing rents. However, during the period 1996-2002, the deterioration of the Dinar became a major influence on inflation rates as well as continued commodity scarcity due to problems and constraints encountered with the implementation of the memorandum of understanding.

Al-Wondawi (2010) measures the impact of the general level of prices and money supply on the Dinar for Iraq and for the period 1980-2002. The purpose of the study is to examine the economic factors that had a more significant impact on the Dinar exchange rate against the USD. The consumer price index (CPI) is used as an indicator of general inflation and money supply in the narrow sense (M1) is used to express money circulating within the economy. While the researcher reports that the exchange rate for the general price level has slight flexibility in the short term but becomes flexible in the long term. It further argues that the narrower view of money is less influential in its interpretation of the deterioration of the exchange rate in the short term, but more in the long term so that exchange-rate flexibility for the money supply is high. However, the money supply is a significant reason for the explanation of the deterioration of the Dinar exchange rate against the USD. Therefore, the money supply is also included in the model part of this paper.

Al-Qaisi (2005) is about stimulating the monetary policy in tackling inflation with particular reference to Iraq for the period 1981-2001. The study purposes to motivate a monetary policy in dealing inflation and in particular, the inflation witnessed by the Iraqi economy through determining the extent of alignment between monetary policy options and the unusual economic trends experienced by the Iraqi economy. As a result, the study finds that this is evidenced by the increase in the ratio of internal public debt represented by treasury transfers to the Iraqi central bank, where this ratio represented $99.7 \%$ of the total public debt with the Iraqi banking system. The central bank of Iraq had the most significant percentage, $63.8 \%$. However, the various data indicate that the monetary policy in Iraq did not abate the effects on real variables, but receded into their effect on monetary variables toward tackling inflation due to dependency on monetary policy to the fiscal policy set by the central decisions. While the researcher argues that individuals kept the money for reserves and speculation rather than in savings deposits and with the high cost of keeping the money as a result of the rise in the total level of prices, individuals are increased their demand for goods, which lead to a rise in prices again.

\section{Data and Analysis}

This section explains the variables in the model, gives the stationarity resuts and presents the ECM results. The model used in this article is based on Fisher Equation on the quantity theory of money given in Eq. 1 (Fisher, 1963). This equation can alternatively be written as in Eq. 2 . In a simple version of quantity theory money and it is assumed that the real income grows at the longrun rate and the velocity of money remains constant (Brau, 1971). Therefore, $\% \Delta V \approx 0$ and inflation can be represented as in Eq 3.

$$
\mathrm{M} \cdot \mathrm{V}=\mathrm{P} \cdot \mathrm{Q}
$$

Where $M$ is the money supply; $V$ is the velocity of money, which measures how much a single Dinar of money supply spend contributes to GDP; $P$ is the prevailing price level; $Q$ is the quantity of goods and services produced in the economy or total volume of goods transacted or index of physical volume of trans-actions.

$$
\begin{gathered}
\% \Delta \mathrm{M}+\% \Delta \mathrm{V}=\% \Delta \mathrm{P}+\% \Delta \mathrm{Q} \\
\text { inflation } \approx \% \Delta \mathrm{M}-\% \Delta \mathrm{Q}
\end{gathered}
$$

Figure 1: Quantity Theory of Money Variables for NRI 


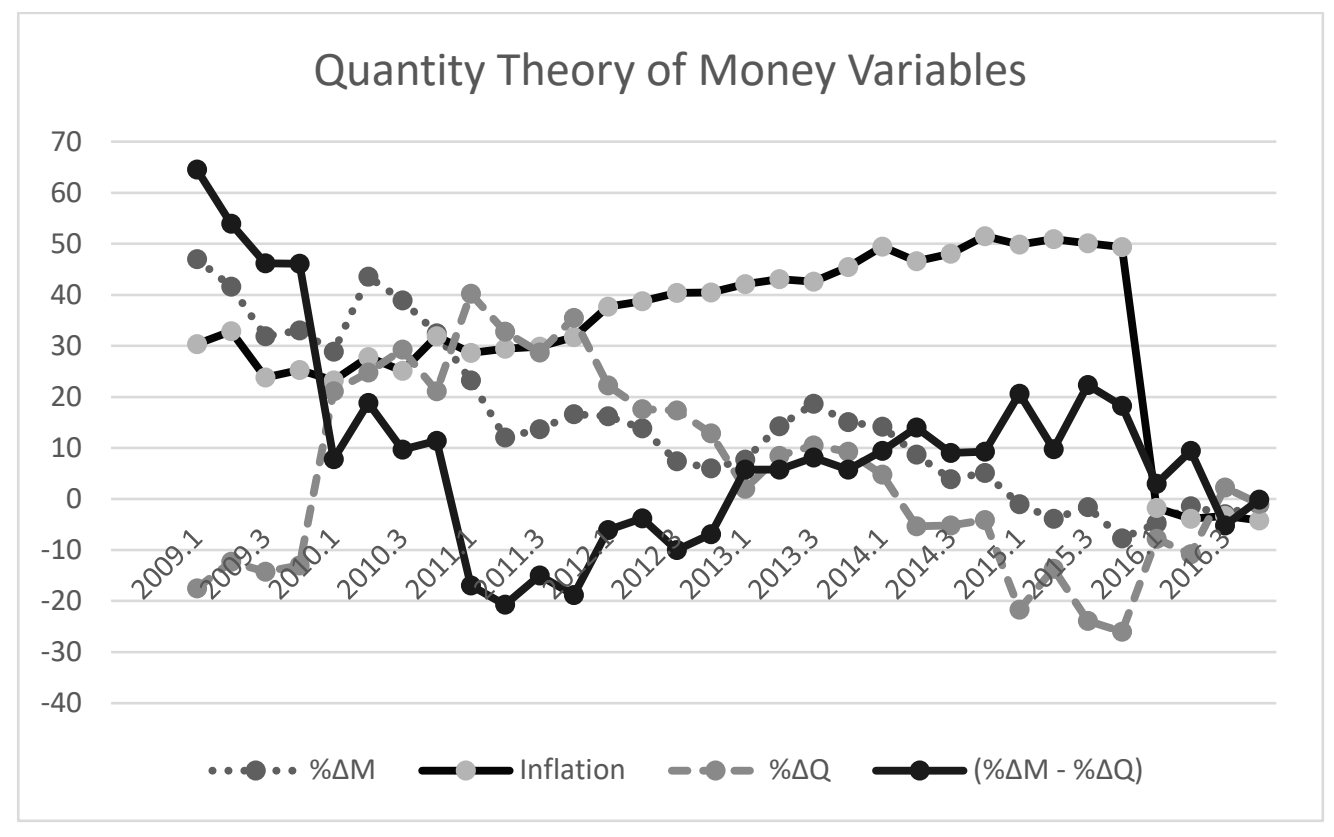

In Figure 1 there is a large deviation between the variables inflation and $\% \Delta \mathrm{M}-\% \Delta \mathrm{Q}$, which might me the contribution of the velocity of money up to $50 \%$. This can be due to the fact that the velocity of money is not constant. However, even when the velocity of money is not constant the deviation is larger than Benk et al. (2010) predictions. The reason for this might be that there are other variables that affect inflation. Therefore, the exchange rates of the major currencies in the NRI for the period 2008-2016 is included in the model. In addition, there is a sharp decrease in the inflation rate in 2016:Q1. 50\% drop in oil prices, the occupation of neighboring provinces by Islamic State (IS) militants, and the suspension of fiscal transfers from Baghdad to the Regional Government have resulted in a government-budget crisis of epic proportions. State-sector salaries have gone unpaid for months at a time, banks had no cash to fund depositors' withdrawals, arrears to construction contractors were piling up, and billions of dollars in payments due to foreign oil companies have not been made. Consumer spending has collapsed, property prices have crashed, occupancy rates at four and five star hotels have plummeted, and work on many projects has come to a virtual standstill (DeWeaver, 2016). Many government workers (including teachers, soldiers and other employees) have not been paid for 3 months from as of October 2015 and the imposition of a compulsory savings system by the regional government on public employees' salaries led to a decrease in the demand for goods and services in NRI (Omar, 2017).

\subsection{The Model}

This study uses the following model:

$$
y_{t}=\beta_{0}+\beta_{1} M_{t}+\beta_{2} G D P_{t}+\beta_{3} U S D_{t}+\beta_{4} E_{t}+\beta_{5} T L_{t}+\varepsilon_{t}
$$

$y$ : Consumer price index general index number in region (Level; KRG, 2017a).

M: Money supply (Level; Central Bank of Iraq Annual Report, 2018).

GDP: Gross domestic product (Level; Central Bank of Iraq Annual Report, 2018).

USD: Dollar exchange rate (Level; KRG, 2017b).

E: Euro exchange rate (Level; KRG, 2017b).

TL: Turkish Lira (TL) exchange rate (Level; KRG, 2017b).

$\varepsilon$ : A term of stationary error. 
The autoregressive distributed lag model (ARDL) is used to test for cointegration and to estimate long-run and short-run dynamics. The ARDL model offers an advantage when handling variables that may include a mixture of stationary and non-stationary time-series. Another advantage of the model was that it is easy to implement and interpret since it involves only a single-equation arrangement. A third advantage is that different variables of the model could be assigned different lag-lengths (Pesaran et al., 2001). In order to find the long-run and short- run relation, the dynamic ECM is used, which is derived by ARDL model. The model is as follows:

$\Delta y_{t}=\alpha_{0}+\sum_{i=1}^{j} \delta_{i}^{y} \Delta y_{t-i}+\sum_{i=0}^{m} \delta_{i}^{M} \Delta M_{t-i}+\sum_{i=0}^{g} \delta_{i}^{G D P} \Delta G D P_{t-i}+\sum_{i=0}^{d} \delta_{i}^{D} \Delta U S D_{t-i}+\sum_{i=0}^{e} \delta_{i}^{E} \Delta E_{t-i}+$ $\sum_{i=0}^{t} \delta_{i}^{T} \Delta T L_{t-i}+\lambda_{1} y_{t-1}+\lambda_{2} M_{t-1}+\lambda_{3} G D P_{t-1}+\lambda_{4} U S D_{t-1}+\lambda_{5} E_{t-1}+\lambda_{6} T L_{t-1}+\varepsilon_{t}^{*}$

where $\delta^{a} \mathrm{~s}\left(a=y, M, G, D, E, T\right.$ indexes) are short-run parameters and $\lambda_{1}$ to $\lambda_{6}$ are long-run parameters. To test cointegration, the null hypothesis is set to $H_{0}: \lambda_{1}=\lambda_{2}=\lambda_{3}=\lambda_{4}=\lambda_{5}=\lambda_{6}=0$ against the alternative hypothesis $H_{1}$ is at least one of the $\lambda^{\prime}$ s not zero. A rejection of the null hypothesis implies that the model has a long-run (cointegration) relationship.

The Akaike Information Criterion (AIC) was used to select the orders of the lags for the specification in the ARDL model. AIC is a popular model selection criterion. Even though it has a risk of over-fitting the model, it would not under-fit. The lag length that minimizes AIC is then selected. After the suitable lag structure for Eq. 5 is selected, the Johansen cointegration test is used to test the model for whether there was a long-run relationship between these variables. If a long-run (cointegration) relationship is observed, we could estimate the long-run model (levels model) and the short-run model (conventional error-correction model). If a long-run (cointegration) relationship among these variables is identified, all of the first difference of the variables in the Eq. 5 were equal to zero, and the long-run model could be formulated as the following form:

$$
y_{t}=\gamma_{0}+\gamma_{1} M_{t}+\gamma_{2} G D P_{t}+\gamma_{3} U S D_{t}+\gamma_{4} E_{t}+\gamma_{5} T L_{t}+\epsilon_{t}
$$

where the long-run coefficients $\gamma_{0}=-\alpha_{0} / \lambda_{1} ; \gamma_{1}=-\lambda_{2} / \lambda_{1} ; \gamma_{2}=-\lambda_{3} / \lambda_{1} ; \gamma_{3}=-\lambda_{4} / \lambda_{1} ; \gamma_{4}=-\lambda_{5} / \lambda_{1} ; \gamma_{5}=-\lambda_{6} / \lambda_{1}$ and $\epsilon_{t}$ is the random error. In order to estimate the short-run relationship, the error correction model version model from the ARDL model in Eq. 5 was used as follows:

$\Delta y_{t}=\alpha_{2}+\sum_{i=1}^{j} \delta_{i}^{y_{2}} \Delta y_{t-i}+\sum_{i=0}^{m_{2}} \delta_{i}^{M_{2}} \Delta M_{t-i}+\sum_{i=0}^{g} \delta_{i}^{G D P_{2}} \Delta G D P_{t-i}+\sum_{i=0}^{d} \delta_{i}^{D_{2}} \Delta U S D_{t-i}+\sum_{i=0}^{e} \delta_{i}^{E_{2}} \Delta E_{t-i}+$ $\sum_{i=0}^{t} \delta_{i}^{T_{2}} \Delta T L_{t-i}+\psi E C M_{t-1}+\varepsilon_{t}^{* 2}$

The coefficient of the error correction term ECM $t-1$ in Eq. 7 is the speed of adjustment from the short-run to the long-run, which is expected to be negative and statistically significant. The model is tested by the diagnostic tests for LM test for serial correlation and normality test.

\subsection{Stationary Tests}

Table 1 presents the results of the stationary testing for the time series of the study variables through using the Phillip-Perron (PP) and the Augmented Dickey-Fuller (ADF) tests, whereas the results reveale most of the variables are not stationary at the level of data based on the PP and the ADF tests. In Table 2 all variables become stationary after the first difference has taken according to the PP and the ADF tests.

Table 1: Stationary Tests by Phillips-Perron (PP) and the Augmented Dickey-Fuller ADF Tests for Study Variables

Unit Root Test Table At Level 


\begin{tabular}{|c|c|c|c|c|c|c|c|}
\hline \multicolumn{8}{|c|}{ PP } \\
\hline & & USD & Euro & $\mathrm{TL}$ & GDP & M & Y \\
\hline \multirow{2}{*}{ With Constant } & t-Statistic & -1.518 & -1.764 & -1.511 & -1.391 & -3.268 & -1.176 \\
\hline & Prob. & 0.513 & 0.392 & 0.517 & 0.576 & $0.024^{*}$ & 0.674 \\
\hline \multirow{2}{*}{ With Constant \& Trend } & t-Statistic & -3.617 & -2.327 & -2.756 & -0.749 & 0.333 & -0.869 \\
\hline & Prob. & $0.043^{* *}$ & 0.409 & 0.222 & 0.961 & 0.998 & 0.949 \\
\hline \multirow{2}{*}{$\begin{array}{c}\text { Without Constant \& } \\
\text { Trend } \\
\end{array}$} & t-Statistic & 1.017 & -1.731 & -3.332 & 0.192 & 1.671 & -0.99 \\
\hline & Prob. & 0.915 & $0.079^{*}$ & $0.002^{* * *}$ & 0.736 & 0.975 & 0.282 \\
\hline \multicolumn{8}{|c|}{ ADF } \\
\hline \multirow{2}{*}{ With Constant } & t-Statistic & -1.561 & -1.838 & -1.485 & -1.371 & -3.463 & -0.968 \\
\hline & Prob. & 0.492 & 0.357 & 0.529 & 0.585 & $0.015^{* *}$ & 0.754 \\
\hline \multirow{2}{*}{ With Constant \& Trend } & t-Statistic & -3.811 & -3.995 & -2.795 & -0.755 & 0.204 & -0.869 \\
\hline & Prob. & $0.028^{* *}$ & $0.019^{* *}$ & 0.209 & 0.960 & 0.997 & 0.949 \\
\hline \multirow{2}{*}{$\begin{array}{c}\text { Without Constant \& } \\
\text { Trend }\end{array}$} & t-Statistic & 1.079 & -1.107 & -2.711 & 0.199 & 1.230 & -0.985 \\
\hline & Prob. & 0.923 & 0.238 & $0.008^{* * *}$ & 0.738 & 0.941 & 0.285 \\
\hline
\end{tabular}

Notes: $\left({ }^{*}\right)$ Significant at the $10 \% ;\left(^{* *}\right)$ Significant at the $5 \% ;\left({ }^{* *}\right)$ Significant at the $1 \%$.

Source: The output of EVIEWS program version 7

Table 2: Stationary Tests for The first difference of Study Variables

\begin{tabular}{|c|c|r|r|r|r|r|r|}
\hline \multicolumn{7}{|c|}{ UNIT ROOT TEST TABLE At First Difference } \\
\hline \multicolumn{7}{|c|}{ PP } \\
\hline \multirow{2}{*}{ With Constant } & & D(USD) & D(Euro) & D(TL) & D(GDP) & D(M) & D(y) \\
& t-Statistic & -8.5717 & -4.5501 & -5.6208 & -6.4029 & -3.903 & -5.6688 \\
\cline { 2 - 8 } & Prob. & 0.000 & 0.001 & 0.000 & 0.000 & 0.005 & 0.000 \\
\hline \multirow{2}{*}{ With Constant \& Trend } & t-Statistic & -14.861 & -4.495 & -5.554 & -6.6507 & -5.567 & -5.922 \\
\cline { 2 - 9 } & Prob. & 0.000 & 0.006 & 0.000 & 0.000 & 0.000 & 0.000 \\
\hline \multirow{2}{*}{ Without Constant \& Trend } & t-Statistic & -7.333 & -4.404 & -4.84 & -6.437 & -2.911 & -5.695 \\
\cline { 2 - 9 } & Prob. & 0.000 & 0.000 & 0.000 & 0.000 & 0.004 & 0.000 \\
\hline \multirow{2}{*}{ With Constant } & t-Statistic & -6.74 & -4.613 & -5.415 & -6.433 & -3.838 & -5.669 \\
\cline { 2 - 9 } & Prob. & 0.000 & 0.001 & 0.000 & 0.000 & 0.006 & 0.000 \\
\hline \multirow{2}{*}{ With Constant \& Trend } & t-Statistic & -7.035 & -4.58 & -5.387 & -6.683 & -5.557 & -5.911 \\
\cline { 2 - 9 } & Prob. & 0.000 & 0.005 & 0.001 & 0.000 & 0.000 & 0.000 \\
\hline \multirow{2}{*}{ Without Constant \& Trend } & t-Statistic & -6.641 & -4.518 & -4.845 & -6.47 & -3.009 & -5.695 \\
\cline { 2 - 8 } & Prob. & 0.000 & 0.000 & 0.000 & 0.000 & 0.003 & 0.000 \\
\hline
\end{tabular}

Notes: All variables are significant at the $1 \%$.

Source: The output of EVIEWS program version 7

\subsection{The Johansen Cointegration Test}

Table 3 presents the Johansen cointegration test results in determining the cointegration between the study variables by trace and maximum eigenvalue. As reported the trace and maximum eigenvalue statistics and their values both at $5 \%$ reveals that there is one cointegration equation at $5 \%$ level of significance. These results propose that the suitable model to use is the ECM specification.

Table 4 presents the lag tests used to determine the optimum lag between the variables. SC and $\mathrm{HQ}$ statistics suggest one lag period; however, the majority of statistics suggest two lags. Therefore, the best optimal lag is two periods according to the criteria for choosing optimum lag appropriate for ECM.

Table 3: Trace Effect Coefficient by Johansen Test

\begin{tabular}{|c|c|c|c|c|}
\hline \multicolumn{5}{|c|}{ Unrestricted Cointegration Rank Test (Trace) } \\
\hline Hypothesized & Eigenvalue & Trace & 0.05 & Prob. $^{* *}$ \\
\hline
\end{tabular}




\begin{tabular}{|c|c|c|c|c|}
\hline No. of CE(s) & & Statistic & Critical Value & \\
\hline None ${ }^{*}$ & 0.730608 & 104.2688 & 95.75366 & 0.0114 \\
\hline At most 1 & 0.496730 & 60.98643 & 69.81889 & 0.2063 \\
\hline At most 2 & 0.451519 & 38.32767 & 47.85613 & 0.2879 \\
\hline At most 3 & 0.332669 & 18.50780 & 29.79707 & 0.5287 \\
\hline At most 4 & 0.106494 & 5.160330 & 15.49471 & 0.7916 \\
\hline At most 5 & 0.042827 & 1.444450 & 3.841466 & 0.2294 \\
\hline \multicolumn{5}{|c|}{ Trace test indicates 1 co-integrating eqn(s) at the 0.05 level } \\
\hline \multicolumn{5}{|c|}{$*$ denotes rejection of the hypothesis at the 0.05 level } \\
\hline \multicolumn{5}{|c|}{ Unrestricted Cointegration Rank Test (Maximum Eigenvalue) } \\
\hline Hypothesized & \multirow{2}{*}{ Eigenvalue } & Max-Eigen & 0.05 & \multirow{2}{*}{ Prob.** } \\
\hline No. of CE(s) & & Statistic & Critical Value & \\
\hline None * & 0.730608 & 43.28237 & 40.07757 & 0.0211 \\
\hline At most 1 & 0.496730 & 22.65876 & 33.87687 & 0.5567 \\
\hline At most 2 & 0.451519 & 19.81987 & 27.58434 & 0.3537 \\
\hline At most 3 & 0.332669 & 13.34747 & 21.13162 & 0.4208 \\
\hline At most 4 & 0.106494 & 3.715880 & 14.26460 & 0.8881 \\
\hline At most 5 & 0.042827 & 1.444450 & 3.841466 & 0.2294 \\
\hline \multicolumn{5}{|c|}{ Max-eigenvalue test indicates 1 co-integrating eqn(s) at the 0.05 level } \\
\hline \multicolumn{5}{|c|}{$*$ denotes rejection of the hypothesis at the 0.05 level } \\
\hline
\end{tabular}

Table 4: The Results of Selecting the Optimal Delay Period

\begin{tabular}{|c|c|c|c|c|c|c|}
\hline \multicolumn{9}{|c|}{ VAR Lag Order Selection Criteria } \\
\hline Lag & LogL & LR & FPE & AIC & SC & HQ \\
\hline 0 & -1420.337 & NA & $1.11 \mathrm{e}+29$ & 83.90220 & 84.17156 & 83.99406 \\
\hline 1 & -1264.003 & 248.2956 & $9.66 \mathrm{e}+25$ & 76.82371 & $78.7092^{*}$ & $77.4667^{*}$ \\
\hline 2 & -1219.553 & $54.909^{*}$ & $7.24 \mathrm{e}+25^{*}$ & $76.3266^{*}$ & 79.82829 & 77.52081 \\
\hline
\end{tabular}

Notes: * indicates lag order selected by the criterion. LR: sequential modified LR test statistic (each test at 5\% level); FPE: Final prediction error; AIC: Akaike information criterion; SIC: Schwarz information criterion; HQ: Hannan-Quinn information criterion

Source: The output of EVIEWS program version 7

\subsection{The Results of the ECM}

Table 5 presents the long-run equilibrium between inflation and foreign exchange rates, money supply, GDP as the independent variables in the NRI. The error correction parameter $(-0.29)$ is negative and statistically significant; there is an adjustment from the short-run to the long-run.

In Table 5 there is a positive statistically significant long-run relation between USD and the inflation rate in the NRI during the period 2008-2016. Figure 2 illustrates the percentage of imports from various countries or regions and the trade is dominantly made in USD. In Figure 3 the exchange rate of USD is fairly steady with an average of 1223 Dinars (min value $=1180.89$, maximum value=1311.11 and standart error=35.25). Therefore, a change in the value of USD will have an increasing effect on inflation. For example, a 100 Dinnar increase in USD exchange rate will increase inflation in NRI by $32.49 \%$. Alternatively, the devaluation of the Dinar leads to higher inflation rates because the high exchange rates for the USD would make imported expensive and carries a higher inflation rate in the region. Comparing Figure 1 and Figure 3, inflation and USD show a similar behaviour except for the year 2016.

In Figure 2 on the average Iraqi imports are 15.74\% from China, 26.09\% from Turkey, 30.13\% from Asia (without China and Turkey), 5.35\% from USA and only $17.71 \%$ from continental Europe. Therefore, goods imported from Europe will have a smaller impact on inflation. There is a negative long-run relation between the Euro and the inflation rate, which is statistically significant. In Figure 3 the volatility of Euro is high, which is not good for trade with this currency. One explanation for the negative coefficient for Euro might be that if Euro increases good imported from Europe are substituded with cheaper alternatives and hence a negative relation between Euro and inflation. 
In addition, NRI exports petroleum with USDs and a decrease in the value of Euro made imported good with USD more affordable so increased inflation.

Table 5: The Results of ECM

\begin{tabular}{|c|c|c|c|c|c|c|}
\hline \multicolumn{7}{|c|}{ Vector Error Correction Estimates } \\
\hline \multicolumn{7}{|c|}{ Sample (adjusted): 2008Q4 2016Q4 } \\
\hline \multicolumn{7}{|c|}{ Included observations: 33 after adjustments } \\
\hline \multicolumn{7}{|c|}{ Standard errors in ( ) \& t-statistics in [ ] } \\
\hline Co-integrating Eq: & CointEq1 & & & & & \\
\hline$y(-1)$ & 1.000000 & & & & & \\
\hline \multirow{3}{*}{ USD $(-1)$} & 0.324918 & & & & & \\
\hline & $(0.09248)$ & & & & & \\
\hline & [3.51338] & & & & & \\
\hline \multirow{3}{*}{$E(-1)$} & -0.154196 & & & & & \\
\hline & $(0.05907)$ & & & & & \\
\hline & {$[-2.61040]$} & & & & & \\
\hline \multirow{3}{*}{$\mathrm{GDP}(-1)$} & -0.000782 & & & & & \\
\hline & $(0.00101)$ & & & & & \\
\hline & {$[-0.77224]$} & & & & & \\
\hline \multirow{3}{*}{$\mathrm{TL}(-1)$} & -0.107368 & & & & & \\
\hline & $(0.08478)$ & & & & & \\
\hline & {$[-1.26644]$} & & & & & \\
\hline \multirow{3}{*}{$M(-1)$} & -0.000413 & & & & & \\
\hline & $(0.00042)$ & & & & & \\
\hline & {$[-0.99186]$} & & & & & \\
\hline Error Correction: & D(INFLATION) & $\mathrm{D}$ (USD) & $\mathrm{D}(\mathrm{EURO})$ & $\mathrm{D}(\mathrm{GDP})$ & $\mathrm{D}(\mathrm{TL})$ & $\mathrm{D}(\mathrm{MS})$ \\
\hline \multirow{3}{*}{ CointEq1 } & -0.291285 & 0.139330 & 0.045792 & -27.688 & 0.005437 & -18.76515 \\
\hline & $(0.05305)$ & $(0.16913)$ & $(0.63262)$ & (33.3076) & $(0.48350)$ & $(53.9886)$ \\
\hline & {$[-5.49109]$} & {$[0.82382]$} & [0.07239] & {$[-0.83128]$} & {$[0.01124]$} & {$[-0.34758]$} \\
\hline R-squared & 0.778131 & 0.687205 & 0.417270 & 0.444539 & 0.179577 & 0.352108 \\
\hline Adj. R-squared & 0.645009 & 0.499527 & 0.067632 & 0.111262 & -0.312676 & -0.036627 \\
\hline Sum sq. resids & 641.8448 & 6524.283 & 91283.80 & $2.53 \mathrm{E}+08$ & 53322.39 & $6.65 E+08$ \\
\hline S.E. equation & 5.665001 & 18.06140 & 67.55879 & 3556.999 & 51.63448 & 5765.577 \\
\hline F-statistic & 5.845267 & 3.661631 & 1.193436 & 1.333843 & 0.364807 & 0.905779 \\
\hline Log likelihood & -95.79431 & -134.0568 & -177.5911 & -308.3924 & -168.7204 & -324.331 \\
\hline Akaike AIC & 6.593595 & 8.912535 & 11.55098 & 19.47833 & 11.01336 & 20.44430 \\
\hline Schwarz SC & 7.183128 & 9.502068 & 12.14051 & 20.06786 & 11.60289 & 21.03383 \\
\hline Mean dependent & -1.056667 & 3.185152 & -11.97303 & 312.7652 & -17.32303 & 3760.937 \\
\hline S.D. dependent & 9.508051 & 25.53061 & 69.96620 & 3773.088 & 45.06724 & 5662.804 \\
\hline
\end{tabular}

Note: The complete table can be send if requested by email.

Source: The output of EVIEWS program version 7

Figure 2: Iraqi Import in \%

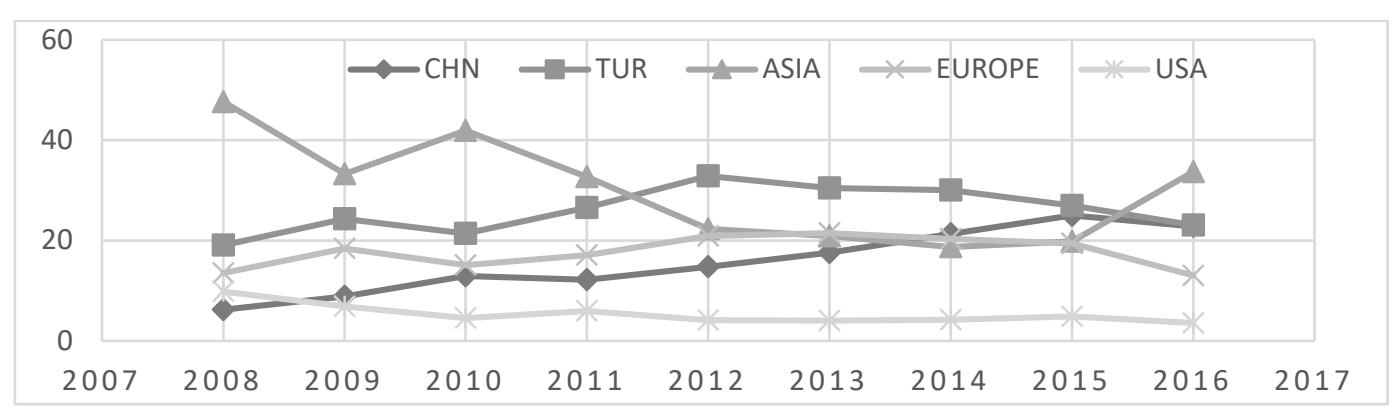

Source: MIT (2019).

Figure 3: Exchange rates 


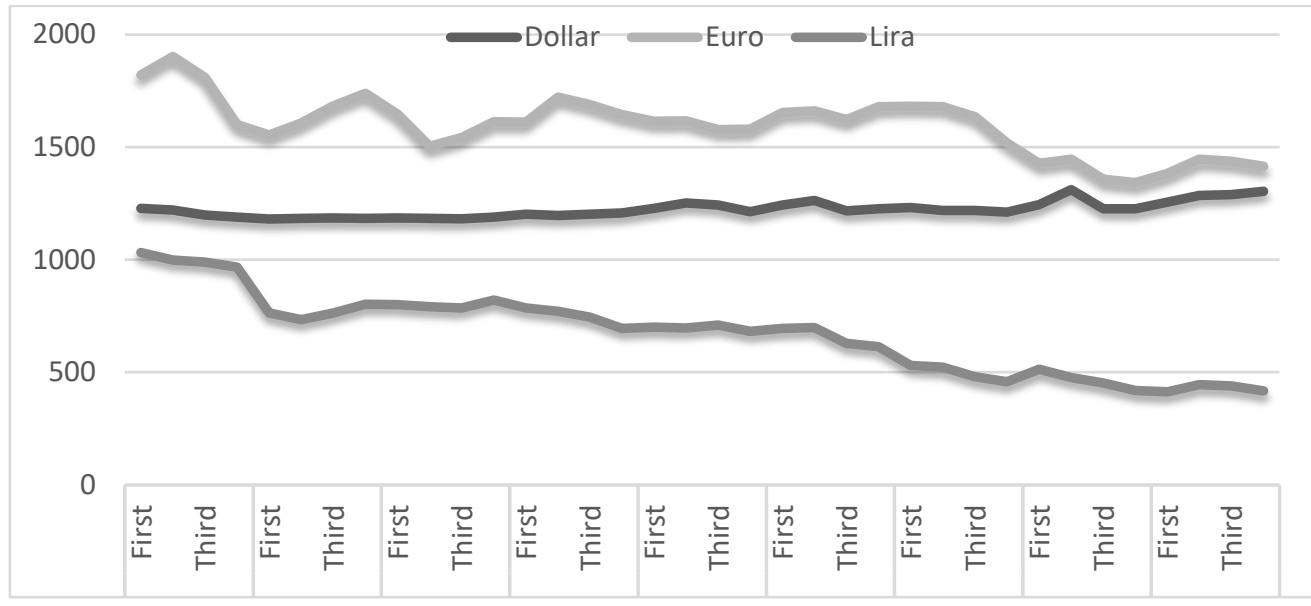

One suprising result is that there is a negative long-run relation between the TL and the inflation rate in the region, but this relation is statistically insignificant. Although on average $26.09 \%$ of imported goods is from Turkey, TL is not playing a dynamic role in NRI; it means that there is no TL's significant impact in economic activities in the region. The reason for this is that most of the goods are imported by USD and not TL.

There is a negative relation between GDP and inflation, which is not statistically significant. This relation is insignificant because the production of goods and services in region is almost non-existent, but it depends on imports of goods and services from neighboring countries especially Turkey.

Table 6: VEC model Equation

\begin{tabular}{|c|c|c|c|c|}
\hline \multicolumn{5}{|c|}{ Dependent Variable: D(INFLATION) } \\
\hline \multicolumn{5}{|l|}{ Method: Least Squares } \\
\hline \multicolumn{5}{|c|}{ Sample (adjusted): 2008Q4 2016Q4 } \\
\hline \multicolumn{5}{|c|}{ Included observations: 33 after adjustments } \\
\hline \multicolumn{5}{|c|}{$\begin{array}{l}\mathrm{D}(\mathrm{y})=\mathrm{C}(1)^{*}\left(\mathrm{y}(-1)+0.324918243049 * \mathrm{USD}(-1)-0.154196481942 * \mathrm{E}(-1)-0.00078180969252^{*} \mathrm{GDP}(-1)-\right. \\
0.107368008673 * T L(-1)-0.000413292078116 * \mathrm{M}(-1))+\mathrm{C}(2) * \mathrm{D}(\mathrm{y}(-1))+\mathrm{C}(3) * \mathrm{D}(\mathrm{y}(-2))+\mathrm{C}(4) * \mathrm{D}(\mathrm{USD}(-1)) \\
+\mathrm{C}(5) * \mathrm{D}(\mathrm{USD}(-2))+\mathrm{C}(6) * \mathrm{D}(\mathrm{E}(-1))+\mathrm{C}(7) * \mathrm{D}(\mathrm{E}(-2))+\mathrm{C}(8) * \mathrm{D}(\mathrm{GDP}(-1))+\mathrm{C}(9) * \mathrm{D}(\mathrm{GDP}(-2))+\mathrm{C}(10))^{*} \mathrm{D}(\mathrm{TL}(-1))+\mathrm{C}(11) * \mathrm{D}(\mathrm{TL}(-) \\
2))+\mathrm{C}(12)^{*} \mathrm{D}(\mathrm{M}(-1))+\mathrm{C}(13)^{*} \mathrm{D}(\mathrm{M}(-2))\end{array}$} \\
\hline & Coefficient & Std. Error & t-Statistic & Prob. \\
\hline$C(1)$ & -0.29129 & 0.05305 & -5.49109 & 0.0000 \\
\hline$C(2)$ & -0.09859 & 0.12277 & -0.80305 & 0.4314 \\
\hline$C(3)$ & 0.01969 & 0.12092 & 0.16283 & 0.8723 \\
\hline$C(4)$ & 0.08578 & 0.05176 & 1.65719 & 0.1131 \\
\hline$C(5)$ & 0.26183 & 0.04849 & 5.39939 & 0.0000 \\
\hline$C(6)$ & -0.01721 & 0.01746 & -0.98569 & 0.3361 \\
\hline$C(7)$ & -0.04359 & 0.01976 & -2.20681 & 0.0392 \\
\hline$C(8)$ & -0.00079 & 0.00034 & -2.33449 & 0.0301 \\
\hline$C(9)$ & -0.00033 & 0.00041 & -0.80296 & 0.4314 \\
\hline$C(10)$ & 0.01424 & 0.02723 & 0.52281 & 0.6069 \\
\hline$C(11)$ & -0.00487 & 0.02607 & -0.18677 & 0.8537 \\
\hline$C(12)$ & 0.00028 & 0.00025 & 1.12156 & 0.2753 \\
\hline$C(13)$ & $-7.67 \mathrm{E}-05$ & 0.00026 & -0.29975 & 0.7675 \\
\hline R-squared & 0.778131 & \multicolumn{2}{|c|}{ Mean dependent var } & -1.056667 \\
\hline Adjusted R-squared & 0.645009 & \multicolumn{2}{|c|}{ S.D. dependent var } & 9.508051 \\
\hline S.E. of regression & 5.665001 & \multicolumn{2}{|c|}{ Akaike info criterion } & 6.593595 \\
\hline Sum squared resid & 641.8448 & \multicolumn{2}{|c|}{ Schwarz criterion } & 7.183128 \\
\hline Log likelihood & -95.79431 & \multicolumn{2}{|c|}{ Hannan-Quinn criter. } & 6.791955 \\
\hline Durbin-Watson stat & 2.486014 & & & \\
\hline
\end{tabular}

Source: The output of EVIEWS program version 7

The relation between the money supply and the inflation rate is not significant because money supply in the northern region government from 2014 till now depends on revenues of oil exported; 
independent from the money supplied in the Iraqi economy. In the analysis, money supply by the Iraqi Central Bank was used as the money supply variable, but the amount of money supply in the $\mathrm{NRI}$ is not proportional to the amount offered by the Central Bank, there is no advanced banking system in the region to bring the money supply as credits to the region (Borroz, 2014). USD is also used in domestic transactions (Quora, 2017; DFR, 2019). The amount of Dinar coming into the region consists of $90 \%$ of the oil export revenues converted into Iraqi dinar and this money is paid to the market. Therefore, the NRI money supply will depend on the oil revenues and the USD, which makes money supply variable statistically insignificant.

The results of the estimate demonstrate that the study variables account for about $77 \%$ variation in the inflation rate in NRI over the period 2008-2016 and $23 \%$ can be due to other factors not taken in the model.

Table 7: Residual Normality Tests

\begin{tabular}{|c|c|c|c|c|c|c|c|c|c|c|c|}
\hline \multicolumn{12}{|c|}{ VEC Residual Normality Tests } \\
\hline \multicolumn{12}{|c|}{ Orthogonalization: Cholesky (Lutkepohl) } \\
\hline \multicolumn{12}{|c|}{ Null Hypothesis: residuals are multivariate normal } \\
\hline \multicolumn{12}{|c|}{ Sample: 2008Q1 2016Q4 } \\
\hline \multicolumn{12}{|c|}{ Included observations: 33} \\
\hline $\begin{array}{l}\text { Co } \\
\mathrm{mp}\end{array}$ & Skew. & Chi-sq & df & Prob. & Kurt. & Chi-sq & df & Prob. & Jarque-Bera & $\mathrm{df}$ & Prob. \\
\hline 1 & 0.173 & 0.166 & 1 & 0.684 & 3.176 & 0.043 & 1 & 0.837 & 0.209 & 2 & 0.9010 \\
\hline 2 & 0.506 & 1.408 & 1 & 0.235 & 3.207 & 0.059 & 1 & 0.808 & 1.467 & 2 & 0.4803 \\
\hline 3 & 0.037 & 0.008 & 1 & 0.930 & 2.453 & 0.412 & 1 & 0.521 & 0.419 & 2 & 0.8109 \\
\hline 4 & -0.853 & 3.999 & 1 & 0.046 & 3.435 & 0.260 & 1 & 0.610 & 4.259 & 2 & 0.1189 \\
\hline 5 & -0.297 & 0.486 & 1 & 0.486 & 2.534 & 0.299 & 1 & 0.585 & 0.785 & 2 & 0.6755 \\
\hline 6 & 0.281 & 0.436 & 1 & 0.509 & 2.552 & 0.276 & 1 & 0.599 & 0.712 & 2 & 0.7006 \\
\hline $\begin{array}{c}\text { Joi } \\
\text { nt }\end{array}$ & & 6.502 & 6 & 0.369 & & 1.348 & 6 & 0.969 & 7.850 & 12 & 0.7968 \\
\hline
\end{tabular}

Source: The output of EVIEWS program version 7

Table 8: Residual Serial Correlation LM Test

\begin{tabular}{|c|c|c|}
\hline \multicolumn{3}{|c|}{ VEC Residual Serial Correlation LM Tests } \\
\hline \multicolumn{3}{|c|}{ Null Hypothesis: no serial correlation at lag order $\mathrm{h}$} \\
\hline \multicolumn{3}{|c|}{ Sample: $2008 Q 12016 Q 4$} \\
\hline \multicolumn{3}{|c|}{ Included observations: 33} \\
\hline Lags & LM-Stat & Prob. \\
\hline 1 & 38.22537 & 0.3687 \\
\hline 2 & 32.14575 & 0.6525 \\
\hline 3 & 29.09319 & 0.7860 \\
\hline 4 & 61.69078 & 0.0049 \\
\hline 5 & 33.32404 & 0.5965 \\
\hline 6 & 38.77110 & 0.3458 \\
\hline 7 & 24.33820 & 0.9303 \\
\hline 8 & 39.58875 & 0.3129 \\
\hline 9 & 24.19364 & 0.9332 \\
\hline 10 & 36.80780 & 0.4313 \\
\hline 11 & 28.41038 & 0.8123 \\
\hline 12 & 45.94537 & 0.1239 \\
\hline
\end{tabular}

Source: The output of EVIEWS program version 7

Table 6 displays the error correction terms and the thirteen estimated parameters $\mathrm{C} 1, \mathrm{C} 2$...C13 that belong to this equation. The coefficient of $C(1)$ is -0.291285 which is negative and also statistically significant at the $1 \%$ level. Hence, the associated co-integrating equation is valid and there 
is a long-run or equilibrium relation between inflation, the exchange rates of the major currencies (USD, Euro, TL), GDP and money supply.

Tables 7 and 8 present the test results for normality and autocorrelation. These tables approve that the residuals can be considered to be normal and have no-autocorrelation relation. VEC Residual Normality Tests under the null hypothesis that residuals are multivariate normally distributed is not rejected due to all the model's probability or p-values more than 0.05 . Likewise, the VEC residual serial correlation LM test under the null hypothesis shows that there is no serial correlation. Thus, the null hypothesis is not rejected up to lag 11 at 1 percent level. However, the tests only rejected serial correlation up to lag 4.

\section{Conclusions}

The motivation of this study is to show that the main reason for inflation in NRI is not an endogeneous variable like money supply but an exogeneous variable (for NRI) like USD exchange rate. In addition, it examines and tries to identify all possible other factors affecting inflation in the NRI for the period 2008 - 2016. The most important variable during this time period is identified as USD. According to findings of the study, there is a positive statistically significant long-run relation between the exchange rate of the USD and inflation in the NRI and almost $80 \%$ of goods are imported from regions where most probably trade is done with USD. Furthermore, the devaluation of the Dinar leads to higher inflation rates because high exchange rates for the USD would make imports expensive, carries this effect as a higher inflation rate in the NRI. Therefore, and fiscal or monetary policy that has a stabilizing effect on exchange rater of USD will have a stabilizing effect on inflation.

Moreover, results of the study indicate that there is a negative long-run relation between Euro and the inflation rate. In NRI the value of USD was fairly constant while the volatility of Euro was high, which is not good for trade with this currency. One explanation for the negative coefficient for Euro might be that if Euro increases good imported from Europe are substituded with cheaper alternatives and hence a negative relation between Euro and inflation. In addition, NRI exports petroleum with USDs and a decrease in the value of Euro made imported good with USD more affordable so increased inflation.

The other findings of the study can be sorted as such: There is no long-run relation between the $\mathrm{TL}$ and the inflation rate in the region during the analysis period. Although Turkey is an important trading partner with NRI, the TL has not played a dynamic role in Iraqi and NRI markets; it means that TL has no significant impact in economic activities in the region. Besides, there is no long-run relation between GDP and inflation, because except of oil products there is no significant production of goods and services in region. In addition, there is no long-run relation between money supply and inflation, because income of NRI government from 2014 till now depends not on money printed but on revenues of oil exported independent from Iraq central bank. The number of observations is small, so some of the insignificant variables might be detected as significant in the future.

In the light of the results and conclusions the current study reached, the researchers endorse the subsequent recommendations. It is necessary for NRI authorities to direct their efforts towards industrial or agricultural ventures, tourism with the participation of the private sector because that will contribute to decrease inflationary pressures caused by USD and thus will lead to reduce imports and increase domestic production.

It is the responsibility of the Iraqi central bank to work on the convergence of parallel exchange rates and official exchange rates. Volatility in exchange rates is not good for demand in goods and hence increases the prices of goods. It is necessary to reduce speculation in foreign exchange markets in the Iraqi provinces, especially in the region.

\section{References}


Abbas, S. N. (2008). The Effect of Inflation on the Exchange Rate of the Iraqi Dinar for the Period 1990 - 2005. Journal of Baghdad college of economic sciences, 6.

Akaike, H. (1998). Information Theory and an extension of the maximum likelihood principle. In Selected papers of hirotugu akaike (pp. 199-213). Springer, New York, NY.

Al-Qaisi, Q. S. (2005). Activitating the Monetary Policy in Dealing Inflation with Particular Reference to Iraq for the Period 1981 - 2001. Baghdad: University of Mustansiriya College Management and Economics - Badgdad.

Al-Wondawi, N. M. (2010). Measuring the Effect of the General level of Prices and the Presantation of Cash on Exchange Rate of the Iraqi Dinar for the Period 1980 - 2002. Journal of Administration and Economics University of Karbala, 113.

Aqrawi, F. A. E. (2018). The analysis of relationship between inflation and foreign exchange rates in the Northern region of Iraq for the period (2008 - 2016). https://tez.yok.gov.tr/Ulusal TezMerkezi/TezGoster?key=hcgrYffRbz0Z44UJEuLtwTcB2x2fzSHPc6lwliwiicSay8YCDkn72nHiYSD9PQ sa. Siirt: Institute of Social Sciences.

Badawah, S. O. (2015). Analysis of the Relationship Between Foreign Exchange Rate and Inflation Rate. Iraqi Journal for Economic Sciences, 141.

Benk, S., Gillman, M., and Kejak, M. (2010). A banking explanation of the US velocity of money: 1919-2004. Journal of Economic Dynamics and Control, 34 (4), 765-779.

Borroz, N. (2014). Turkey's Energy Strategy: Kurdistan over Iraq. Turkish Policy Quarterly, 13(2), 103-110.

Brau, E. H. (1971). The Variability of Velocity and Credit Ceilings. International Monetary Fund. 18 (3), 473-507.

Central Bank of Iraq Annual Report. (2018). Annual Report of Iraq. Bagdad: Central Bank Iraqi.

DeWeaver, M. (2016). Iraqi Kurdistan Economic Report 2016: Kurdistan's Great Recession. https://auis.edu.krd/iris/sites/default/files/Kurdistan\%27s\%20Great\%20Recession_1.pdf (24.02.2019).

DFR. (2019). Currency. Department of Foreign Relations. https://dfr.gov.krd/p/p.aspx?p=291 $\& \mid=12 \& r=367$ (24.02.2019).

Dickey, D., and Fuller, W. (1981). Likelihood Ratio Statistical for Autorgressive Time Series with a Unit Root. Econometrica: Journal of Econometric Society, 49(4), 1057-1072.

Eas, A. K. (2013). Analysis of Inflation Rate in Iraq for Period 2000 - 2010. Journal of Baghdad College of Economic Sciences, 46.

Fisher, Irving (1963). The Purchasing Power of Money. New York: Kelley.

FT. (2019). Iraq steps up pressure on Kurdistan with currency transfer ban. The Financial Times. https://www.ft.com/content/17e5df24-a86d-11e7-93c5-648314d2c72c (24.02.2019).

Hannan, E. J., and Quinn, B. G. (1979). The determination of the order of an autoregression. Journal of the Royal Statistical Society: Series B (Methodological), 41(2), 190-195.

Johansen, S. (1991). Estimation and hypothesis testing of cointegration vectors in Gaussian vector autoregressive models. Econometrica: Journal of the Econometric Society, 1551-1580.

Khanjar, M. M. (2010). Pathways of Inflation in the Iraqi Economy for the Period 1990 - 2007. Badgdad: University of Mustansiriya College Management and Economics - Badgdad.

KRG. (2017a). Ministry of Planning, Region's Statistics Authority, Consumer Price Index Unit. Erbil: Ministry of Planning. 
KRG. (2017b). Ministry of Commerce and Industry, Directorate of General Trade, Chamber of Commerce and Industry in Erbil, Sulaymaniyah, and Duhok. Unpublished records., Erbil, Sulaymaniyah, and Duhok.

MIT. (2019). Where does Iraq import from? (2007-2017). https://atlas.media.mit.edu/en/visualize/stacked/hs92/import/irq/show/all/2007.2017/ (24.02.2019).

Omar, L. O. (2017). Analaysis of consumer price indices in Erbil governorate for the period 2009 2015. Journal of Anbar University for Economic and Administrative, 217.

Pesaran, M.H., Shin, Y., and Smith, R.J. (2001). Bounds testing approaches to the analysis of level relationships. Journal of Applied Econometrics 16, 289-326.

Phillips, R., and Perron, P. (1988). Testing for a Unit Root in Time Series Regression. Biometrika, 57, 335 - 346.

Quora. (2017). What currency is in use in Erbil? https://www.quora.com/What-currency-is-in-usein-Erbil (29.04.2019).

Schwarz, G. (1978). Estimating the Dimension of a model. The Annals of Statistics, 6(2), 461-464.

Smaail, K. K. (2008). Impact of Iraqi Dinar Exchange Rate in Commercial (Internal and External) for Erbil city during 1994 - 2006. Erbil: Salahaddin University - Erbil.

Watson, P., and Teelucksingh, S. (2002). A Practical Introduction to Econometric Methods: Classical and Modern. Indies: The University of the WestIndies Press. 